\title{
Social policy frameworks of exclusion: the challenge of protecting the social rights of "undocumented migrants" in Quebec and Shanghai ${ }^{1}$
}

\author{
Dr. Jill Hanley² \\ Associate Professor, McGill University, School of Social Work \\ 3506 University Street, \#300, Montreal, Qc, Canada, H3A 2A7 \\ jill.hanley@mcgill.ca 1-514-717-4046
}

and

Dr. Ya Wen

McGill University, School of Social Work

\footnotetext{
1 The Canadian portion of this research was supported by the Quebec Fund for Social and Cultural Research (FQRSC) and the Social Sciences and Humanities Research Council (SSHRC).

${ }^{2}$ Corresponding author
} 


\begin{abstract}
This article focuses on the implications of administrative "undocumentedness", arguing that a lack of legal recognition across jurisdictional boundaries has parallels whether international or inter-municipal. In Canada and China, migrant workers only began receiving significant public attention in the past 20 years. Canada has had a boom in the use of the Temporary Foreign Worker Program yet tightening immigration procedures overall have led to a rise in the number of undocumented workers. While in China, most rural-to-urban migrants move without transferring their hukou residency registration. The authors argue that there are surprising parallels in the policy frameworks governing access to social rights for undocumented migrants in Quebec and in Shanghai, parallels that create social exclusion. Mutual lessons for addressing the social rights of irregular migrants are discussed.
\end{abstract}

Keywords: Undocumented migrants; migrant workers; social rights; social exclusion; Shanghai, China; Quebec, Canada 


\section{Introduction}

This article offers a reflection on the ways in which the social exclusion of migrant workers through administrative "undocumentedness" poses a surprisingly similar challenge to both Canada (Quebec) and China (Shanghai). For the purposes of this article, we speak of "undocumentedness" not as the complete absence of legal identity papers ${ }^{3}$, but rather the lack of proper documentation that would confer a full access to social rights and implying the lack of legitimate presence within a given jurisdiction (Varsanyi 2006, Meloni et al. 2014). We are concerned about the ways in which the lack of state recognition of the legitimacy of a person's presence in a specific polity interferes with their ability to access the resources necessary for a good quality of life and with their ability to participate in and contribute fully to the collective (Sassen 2002).

Two countries with vastly different populations, different economies and different histories of migration - Canada with a history of immigration supplementing internal migration; China with a history of emigration and, today, a focus on internal migration -Canada and China have nonetheless both found themselves in a situation in which national policy choices have led to an undesired increase in the number of undocumented migrant workers. These migrants and their families then find themselves excluded from the social rights provided by provincial governments, in the case of Canada, and municipal governments, in the case of China.

Here we offer insights from our respective studies on the experiences of undocumented

\footnotetext{
3 In the case of Canada's international migration, this would be stateless persons; in China, this could be children whose birth was never officially registered and who, correspondingly, have no hukou registration.
} 
migrants in Quebec, Canada and Shanghai, China. We begin the article with a brief portrait of the undocumented population in these two locales. The central part of the article reviews the social policies of exclusion, specifically in relation to legal migratory status, labour rights, and access to healthcare, education and housing. Given the influence of this exclusion on migrant workers and their families, we conclude the article with reflections on the lessons that can be drawn from these two case studies and the potential policy solutions to the dilemma of undocumented migrants.

\section{Portrait of migrant workers in Canada and China}

Internationally, there is recognition that international labour migration is a formidable economic and social force, with upwards of 150 million people on the move ( $4 \%$ of the global population), outside of their country of origin either working or seeking work, with men outnumbering women (56\% versus 44\%) (ILO 2015). Workers also migrate within their countries of nationality for work, a phenomenon that also has major implications for development and for the lives of workers (Deshingkar \& Grimm 2005). As a region, North America receives the highest proportion of international labour migrants (25\% of the world's labour migrants) while East Asia receives only 4\% (second lowest) (ILO 2015). In East Asia, demand for labour is satisfied by internal migration instead of international. As we will discuss here, however, in China, the hukou system - the household registration system used by the central government to control people's movements as well as the allocation of jobs and social services - creates many parallels between internal migration within China and international migration elsewhere. In both contexts, mobility without administrative approbation can lead to 
a state of "undocumentedness" with many implications.

In order to understand the reality of undocumented workers in the two jurisdictions of Quebec, Canada and Shanghai, China, we must first consider the reality of migrant workers in general. In Canada, we speak of immigrants, foreign-born individuals now living and working in Canada. ${ }^{4}$ In China, in contrast, we speak of internal, typically rural-to-urban, migrant workers, Chinese citizens who are living and working away from their birth hukou region. As can be seen in Table 1, there are remarkable parallels in migration trends in the two countries, with an increase of migrants with precarious legal status, as we will discuss in later sections.

\section{Migrant Workers in Canada}

While the absolute numbers of migrants in Canada is a tiny fraction of those in China, the proportions are similar. As a colonial settler country, Canada has long had immigration as a cornerstone of economic and political growth. In recent years, however, there has been a shift away from permanent migration towards temporary migration, representing a growth in what many call "precarious status" (Goldring, Berinstein, and Bernhard 2009). In 2000, 227,000 permanent residents and 67,000 temporary foreign workers ${ }^{5}$ (TFWs) entered Canada. Five years later, new permanent residents had increased by $15 \%$ to 262,000 , while the number of TFWs had increased by $42 \%$ to 95,000 . By 2011 , new permanent residents had actually decreased to 249,000 , while the number of TFWs increased by $76 \%$ to reach 167,000 (CIC, 2014). TFWs only represented about $1 \%$ of the Canadian population (StatsCan, 2012), but if

\footnotetext{
${ }^{4}$ Because Canadian citizens are free to move within the country without any need for state approval and without any significant barriers to registering in a new province or city, we do not include here a discussion of the internal migration of Canadians seeking work, although it also represents a significant number.

5 These numbers do not include any dependents that may have accompanied TFW permit holders, while the Chinese numbers cited below do include other household members than the principal breadwinner.
} 
we consider the foreign-born population in Canada in general, we have $21 \%$ of the total (StatsCan, 2013), very similar to China’s 20\% migrants cited below.

Obtaining statistics on the number of undocumented migrants in Canada is extremely difficult (Ellis 2015). The most recent governmental estimates are broad and inexact, offering a range of between 80,000 to 500,000 individuals (Tilson, 2009, Meloni et al. 2014, Magalhaes, Carrasco, and Gastaldo 2010), with general agreement that they are concentrated in the large urban centres of Montreal, Toronto and Vancouver (StatsCan, 2013). Estimates for Montreal range from 40,000 to 200,000 individuals, a very small proportion of both the total number of foreign born living in Montreal and of the city population overall (only 1-3\% of Montreal's nearly 4 million) (StatsCan, 2015). It is important to note that, in contrast to the situation of undocumented migrants in the United States or Europe, the vast majority of undocumented migrants in Canada entered legally and simply have not been able to maintain legal status because their visas have expired and they have not been able to renew their status (Hanley et al. 2006, Goldring, Berinstein, and Bernhard 2009). And while the Canadian government tends to paint this population as a security threat (Crépeau and Nakache 2006, Magalhaes, Carrasco, and Gastaldo 2010), they have generally passed both health and criminality screening prior to entry.

\section{Migrant workers in China}

In the last three decades, China has gone through rapid urbanization, and rural-to-urban migrants have been a large proportion of the increase in urban population. In 2000 , there were more than 100 million migrants in China (NBS, 2000). According to the $1 \%$ population sample survey, there were 147 million migrants in 2005, a 47\% increase (Duan \& Yang, 2009). And 
the recent national census reported that the migrant population has reached 261 million, a $77 \%$ increase and now representing approximately $20 \%$ of China's population (NBS, 2011). Migrants come to cities for employment and economic gain, and most of them were concentrated in central and coastal provinces or provincial cities such as Beijing, Shanghai, Guangdong, and Zhejiang, where economic development was more advanced.

In 2005, there were 5.81 million migrants in Shanghai and 10 years later, in 2015, the number had reached 9.81 million, $40 \%$ of the total city population of 24.25 million (SSB, 2016), making Shanghai one of China's municipalities with the most concentrated migrant population (NBS, 2011). Of note for the purposes of this article, 7.7 million of Shanghai's migrants remained with a rural hukou registration (SSB, 2016), effectively leaving them undocumented in terms of access to urban employment right and welfare services.

\begin{tabular}{|c|c|c|c|}
\hline \multirow{2}{*}{ Year } & \multicolumn{2}{|c|}{ Canada } & China \\
\hline \multirow{2}{*}{2000} & $\begin{array}{c}227,000 \text { new permanent } \\
\text { residents (PR) }\end{array}$ & 67,000 TFWs & 100 million internal migrants \\
\hline \multirow{2}{*}{2005} & 262,000 new PR & 95,000 TFWs & 147 million internal migrants \\
& $15 \%$ increase & $42 \%$ increase & $47 \%$ increase \\
\hline \multirow{2}{*}{2011 (last } & 249,000 PR & 167,000 TFWs & 261 million internal migrants \\
Cdn census) & $5 \%$ decrease & $76 \%$ increase & $77 \%$ increase \\
\cline { 2 - 4 } Chinese & $21 \%$ of total population foreign-born & $20 \%$ of Chinese population \\
\cline { 2 - 4 } census) & \multicolumn{2}{|c|}{ Montreal's undocumented population: } & Undocumented in Shanghai: \\
& \multicolumn{2}{|c|}{$\begin{array}{c}\text { Estimated 40,000-200,000 } \\
1-3 \% \text { of urban population }\end{array}$} & $31 \%$ of urban population \\
\hline
\end{tabular}

\section{Table 1: Migration parallels in Canada and China, as cited in text}

As we can see in this table, both Canada and China have experienced important growth and parallel trends in the number of migrant workers. Policy differences, however, have resulted in differing proportions of workers facing social exclusion. 


\section{Policy frameworks of social exclusion}

According to Sen (2000), social exclusion can be a combination of deprivations that causes individuals' and groups' incapability to participate in social, economic, political and cultural systems. While social exclusion is a multidimensional concept and varies among studies (Hick 2012), Burchard et al.'s definition is appropriate for the current discussion: an individual is socially excluded if he or she is a geographical resident in a society, but for reasons beyond his or her control, he or she cannot participate in the normal activities of citizens in that society. The normal activities in which an individual may wish to participate varies according to social context (Burchardt et al., 1999). Social policy can function as a part of mechanism that acts to systematically connect or detach groups of people from the social, economic, political or cultural mainstream (Walker \& Walker 1997, Giddens 1998), or access social rights in the case of undocumented migrants.

In this section, we review the different ways in which national migration policy has created a framework of exclusion for undocumented workers in both China and Canada. We are concerned about the way in which social policy, out of concern for jurisdictional and citizenship entitlements, has been intentionally designed to exclude undocumented workers (Chan 2010, Wu 2010, Goldring \& Landholt 2013, Preibisch \& Otero 2014), creating a situation in line with Sen's (2000) definition of social exclusion. We draw upon case studies of the jurisdictions of Shanghai and Quebec, each responsible for the enforcement of labour standards and the provision of social benefits for their local populations, and critique the labour, health, education and housing exclusions faced by undocumented and other migrant workers. 


\section{Legal Migratory Status}

\section{Migration status in Quebec, Canada}

Migrants to Quebec have their immigration status determined principally by the federal government. As mentioned above, undocumented migrants in Canada have overwhelmingly entered Canada legally, having passed the health and security screenings required in order to obtain a temporary residence permit for such activities as tourism, post-secondary education or employment. These people can become undocumented for a number of reasons: they cease to do the activity for which they entered (i.e. stop studying or working); their visa expires and they do not apply to renew it; their application for a visa renewal is denied (Magalhaes, Carrasco, and Gastaldo 2010).

It is believed that a particularly large proportion of those who become undocumented were originally refugee claimants whose claims were denied. Rather than leave the country, they choose to live in Canada undocumented. Since the 9/11 terrorist attacks in the United States, Canada has implemented a series of reforms to the refugee determination system that many advocates argue pushes refugee claimants into illegality (Arbel and Brenner 2014). The first was the 2002 "Safe Third Country" agreement with the United States. In effect since 2004, this agreement prohibits refugee claims in Canada by people who have passed through the United States, and vice versa. While exceptions exist for people with family members in Canada, many others who wanted to claim asylum in Canada for a host of reasons (personal, political) found themselves unable to take the legal route of a refugee claim. More recently, in 2012, major reforms were introduced that offered expedited (read perfunctory) treatment of refugee claims from "designated countries of origin", designated by the Canadian state to be unlikely to produce true, rather than "bogus", refugees (Bond and Wiseman 2014). The result has been 
fewer claims and people from legitimate refugee-producing states such as Mexico and Hungary (Roma population) being pushed into illegality.

The second group adversely affected by recent reforms is temporary foreign workers (TFWs) (Wang and Zong 2014, Foster 2012). This programme has exploded since 2002, when the government opened the programme to a much broader spectrum of occupations, particularly those designated "low-skill". Before 2002, there were specific programs for farmworkers and domestic caregivers, but since then use of the programme has exploded into many sectors (Fudge and MacPhail 2009, Wang and Zong 2014). When their dependents are included in the statistics, TFW entries to Canada have surpassed permanent residents since 2007 (Faraday 2012). While most TFWs would like to be able to settle permanently in Canada, only those with jobs requiring post-secondary training are generally able to do so. When the government introduced the "4-and-4" rule in 2011, it meant that TFWs were limited to 4 years of temporary work permits before being forced to leave Canada for 4 years. While higher skilled TFWs were able to apply for permanent residency after 4 years, low-skill workers could not. There is a concern that, since June 2015, many low-skill TFWs may be being pushed into illegality because they can no longer renew their work permits and they cannot afford to return home to un- or underemployment.

Life is very difficult for undocumented migrants in Canada. They are excluded from virtually all public services and are subject to detention and rapid deportation if they are apprehended by immigration authorities (Magalhaes, Carrasco, and Gastaldo 2010, Meloni 2013, Varsanyi 2006). Their options for regularization are limited.

Migration status in Shanghai, China 
Similarly, migrant workers in China are intentionally excluded from permanent residence in their host cities, residency which is required if they are to enjoy full health and social welfare services within the jurisdiction. Yet their labour is in high demand. Under the original hukou system, population mobility was forbidden, especially from rural to urban, under the command economy. It was stipulated in the document 'Interim regulations on urban household administration" that "all those who move should first notify the local public security offices of change of residence, cancel the census record of the former abode, and apply for a change-ofresidence permit." (Article 5).

In the late 1970s China started implementing more open economic policies. Rural workers began migrating to cities for employment as a result of long-term rural economic failure and the attraction of industrial revival in the cities. This unauthorized migration was at first seasonal, with farmers spending part of the year in cities and returning home during harvest seasons. Faced with growing irregular population movements and in response to the undeniable demand for more workers in the cities, the state gradually loosened the mobility restrictions of the hukou system. In 1984, the State Council decided to allow farmers and their dependents to move to designated towns for permanent settlement, referred to as "blue seal" hukou, provided they met certain conditions so that they did not create a financial burden to the State (Chan \& Zhang, 1999). The "blue seal" hukou policy was terminated in the late 2000 s, however, as the growing numbers of well-off migrants who wanted to transfer their hukou status to permanent urban citizens through “blue seal” hukou created great pressure on metropolises' public services.

In 1985, temporary residence permits were proposed by the Ministry of Public Security, which allowed rural migrants to legally work and reside in cities without acquiring local hukou 
registration (Liu, 2001). This resulted in what some researchers called an "incomplete urbanization" and an urban underclass with an inferior socio-economic status, for the residence of these rural migrants in cities were only temporary with being excluded to social benefits enjoyed by their urban counterparts.

Moreover, there were strict procedures for obtaining the permits, which expired every six months, and migrants without valid temporary residence permits faced compulsory detention and repatriation to their home origins. In 1992, the forced detention and repatriation system was abolished.

In contrast to the political slogan "to build up a harmonious society" adopted by the political authorities with the intention of reducing tensions and social conflicts, there has been a widening income gap and growing disparities between rural and urban citizens. In response to the social outcry for equality of opportunities and rights for migrant workers, the government began adopting more flexible policies in 2000; restrictions on rural-to-urban migration were further reduced and equal opportunities were promoted, with the goal of eventually integrating the local and migrant labour markets in urban areas. Aiming to maintain economic and social stability, the central government has decentralized power to local governments in the process of economic and welfare reform. Local governments now have autonomy in making hukou transfers and determining relevant welfare policies in accordance with local interests. For example, in July 2014, the State Council proposed the "Opinion to further reforming the hukou system in China", which aims to reduce barriers to rural-to-urban migrants transferring their status to urban citizens, allowing them to enjoy equal services and welfare entitlements with urbanites (State Council, 2014). 
The city of our case study, Shanghai, is applying Point Redemption Policy that allows migrants access to certain public services after passing the points test, similar to the visa schemes that have existed for international migrants since 2013 (and in fact, very similar to the points system used by Canada to determine eligibility for permanent residency). The points test includes age, education, occupation, years of work in Shanghai and contribution to Shanghai local social insurance programs. Although the Point Redemption Policy does not provide ways to transfer hukou status to local urban hukou, it reduces the threshold of rural-to-urban migrants' access certain urban public services, such as children's education, public employment services, public health services and family planning services, and legal aid services, etc. (Xinhua news, 2013).

\begin{tabular}{|c|c|}
\hline Canada's International Migration & China's Internal Migration \\
\hline National Citizenship & Urban Hukou \\
\hline Permanent Residency & Residence Permit \\
\hline Temporary Foreign Worker & Temporary Residence Permit \\
\hline Undocumented Migrant & Unregistered Rural-to-Urban Migrant \\
\hline
\end{tabular}

\section{Table 2: Parallels in Migration Policy in Canada and China}

As we can see in this table, both Canada and China have instituted a policy framework for labour migration that applies a continuum from full social inclusion (citizenship or urban hukou) to relative social exclusion (undocumented workers). In both contexts, irregular migrants are seen more as a security threat than a human rights problem. The state is very uncomfortable with the idea of an undocumented population within their cities but responds somewhat differently in the two contexts. Let us turn now to the implications of this undocumented living in terms of labour, health, education and housing. In the case of Canada, these are provincial jurisdictions so we will speak of our case study of Quebec. In China, they 
are municipal responsibilities, so we will speak of Shanghai.

\section{Labour rights}

\section{Labour rights for irregular migrants in Quebec}

Non-citizens in Canada can gain the right to work in a number of ways (Sikka, Lippel, and Hanley 2011). Refugee claimants and international students, for example, can obtain open work permits (giving the right to work in any job) while they are in Canada for the purposes of their visa (Jackson and Bauder 2014, Faraday 2014). TFWs, however, can only work in jobs that the employer has demonstrated they are unable to hire a Canadian worker. Their subsequent work permit is tied to that specific job, removing any labour market mobility (Foster 2012). Of note, however, is that anyone with a legal work permit in Canada is, by law, guaranteed equal treatment with locals in terms of the provincially-administered labour-related benefits such as labour standards, health and safety, worker's compensation and unemployment insurance (Fudge and MacPhail 2009, Sikka, Lippel, and Hanley 2011).

The same cannot be said for those working without a legal work permit, especially for undocumented migrants. Any work without a work permit is illegal and people engaging in undocumented work are effectively excluded from the entire Quebec labour rights regime, unless they can demonstrate that their undocumented work was undertaken "in good faith" (Sikka, Lippel, and Hanley 2011). For example, a refugee claimant (with legal immigration status in Canada) did not realize they needed a work permit. Or a former TFW was told by their employer that their work permit had been renewed when it hadn't been. It is difficult to prove such "good faith", however, so undocumented workers find themselves unprotected from exploitation with non-payment of wages, dangerous work conditions or disrespectful treatment 
a common phenomenon. In addition, Canada Border Service Agency sometimes raids workplaces believed to be employing undocumented workers, which can lead to their detention and rapid deportation with few implications for the employer. This remains an uncommon occurrence but forms the basis of threats used against workers.

\section{Labour rights for migrants in Shanghai}

Unlike undocumented migrants in Canada, rural-to-urban migrants in China have the right to work, but the right is usually not under legal labour protection. Therefore, migrant workers often faced problems in their employment including low income levels, unequal pay, excessive work overtime, and delayed payments or in arrears (Lee, 2012; Wang, Guo, \& Cheng, 2014).

In the 1990s, many cities kept restricted employment in certain industries and occupations for local residents only. Rural-to-urban migrants were required to obtain an 'employment certificate', only possible if the job could not be filled by local residents (Zhu, 1999; Wang, 2006). Since 2003, however, the central government has decreed that migrant workers should enjoy the same rights and status as locals and confirmed the status of migrant workers as "workers", rather than as peasants as indicated in their hukou registration, and stated that they must be treated as other workers, with all the rights and protections stipulated in the Labour Law (State Council, 2003). The Labour Law was revised in 2007 with detailed provisions for labour contracts and protections that favour migrant workers. For example, the new law required all workers, including migrant workers, to have a written contract and stated that any employer with an employee without a written labours contract was required to double his or her wages for each month worked without a contract beginning with the second month (National People's Congress, 2007). 
Furthermore, the State Council proposed "Opinions on Resolving the Problems Faced by Migrant Workers", pledging to resolve problems such as low wages and wage arrears, bringing the labour management of rural migrants into line with legal regulations, job-seeking services and occupational training, etc (State Council, 2006). It also regulated that equal access to labour-related welfare programs should be extended to migrant workers, referred to as the "Urban Five", which is a national insurance program established for migrant workers based on contributions from both employers and employees. It covers basic healthcare, old age pension, unemployment insurance, on-the-job injury, and maternity benefits for working mothers $(\mathrm{Xu}$ et al., 2011). These laws reflect a major shift in central government's attention to labour protection, however, their success is still under doubt. These reforms fail to advance a unified approach for lifting the hukou system's control over migrants and it has decentralized the fiscal responsibilities of labour protection to local government, while taking little responsibility for welfare provision for rural-to-urban migrants (Cheng et al., 2015).

In Shanghai, the government started implementing a "comprehensive insurance system" to extend insurance coverage for on-the-job injuries, hospital treatment, and old-age pension to rural-to-urban migrants in 2002 (Municipal of Shanghai, 2002). The system was updated in 2009 so that rural-to-urban migrants are allowed to participate in the "Urban Five" programs if their employers are willing to contribute (Municipal Shanghai, 2009). However, unlike the national insurance programs that have tri-parties responsibility (workers, employers, and the government), employers are the only contributors to the Shanghai insurance fund. Therefore, migrants with informal employment or self-employed migrants were left unprotected. 


\section{Access to healthcare}

\section{Access to health for migrants in Quebec}

In terms of access to healthcare in Quebec, we again see a stark divide between migrant workers who have work permits versus those who are undocumented (Sikka, Lippel, and Hanley 2011, Rousseau et al. 2013). Those with closed work permits for more than 6 months qualify for the same provincial Medicare as Canadian citizens for the duration of their work contract. In contrast, undocumented are clearly excluded and required to pay out of pocket for all healthcare services. The cost of healthcare in Canada is extremely high and the price is out of reach for most undocumented migrants (Campbell et al, 2014). Private insurance schemes often refuse to insure undocumented migrants outright or the cost is prohibitive. Certain categories of migrants who are in Canada legally but not eligible for Medicare (international students, for example) find that their private insurance excludes particular types of treatment, especially pregnancy and childbirth.

Research on the medically uninsured population shows a number of problems: avoidance of seeking care, delaying of seeking care, or accruing significant debt in order to access care (Hanley et al. 2014, Oxman-Martinez et al. 2005, Rousseau et al. 2008). There is also the significant risk that interaction with the health care system can lead to denunciation to immigration officials. Although hospitals in Quebec are not required to report undocumented migrants to immigration officials - and, indeed, patient confidentiality suggests that they should not - there have been a number of high-profile cases where this occurred though unofficial mechanisms.

Access to free or low-cost healthcare depends on either encountering sympathetic individuals within the public health care system who make an exception of not billing the 
patient (Vanthuyne et al. 2013, Rousseau et al. 2014) or taking advantage of the province's one volunteer-based clinic for uninsured migrants, operated by Doctors of the World, an international NGO.

\section{Access to health for migrants in Shanghai}

After adopting a market economy, China's health care system has been undergoing substantial reform, transforming the previous ways in which the state-owned 'work units' that were responsible for providing health care for their urban employees, while rural residents had to depend on their collective communes for health care (Cooperative Medical Insurance) to emphasizing individual obligations and medical expenditures shared between social pooling and individual accounts (Liu, 2004).

Currently, there are three types of health insurance schemes in China, 'Urban employee basic medical insurance', 'Urban resident basic medical insurance', and 'New cooperative medical schemes'. The first scheme requires the contribution from both employers and employees, but it is only mandatory for employees holding urban hukou. Unemployed urban hukou residents fall into the 'Urban resident basic medical insurance' scheme. Although ruralto-urban migrants work and reside in cities, they are not qualified to the first two schemes because of their rural hukou. Rural-to-urban migrants often have to return to their hometowns for treatment because the reimbursements from the rural cooperative insurance do not cover the medical cost in cities. Under Shanghai's "comprehensive insurance system", participating migrant workers (participation that depends on their employer's willingness to contribute) were insured for their basic medical costs. In 2011, aiming to integrate migrants into urban local employee insurance system, Shanghai implemented a pilot program that allows migrant 
workers to access 'Urban employee basic medical insurance', providing they pay a different contribution rate, usually higher than urban residents. However, many employers resisted having to make contributions for their migrant employees.

\section{Access to education}

\section{Access to education for migrant children in Quebec}

Quebec education law stipulates that all children have a right to education, in line with international human rights standards. The law goes on, however, to suggest that only Quebec residents have access to free education. Therein lies the problem for undocumented children. For while any child with any kind of legal immigration statues easily accesses free public education in the province, undocumented children were, until recently, more or less excluded (Protecteur du citoyen 2014).

Until 2013, many undocumented children were excluded from education because of, either, demands from the school boards for immigration papers proving their legal status or demands to pay tuition well beyond the means of the average family (Meloni et al. 2016, forthcoming). One effect of these demands was often to discourage families from pursuing their efforts to register their children in school out of fear of being denounced to immigration authorities. Another was for children to attend school while their families felt great stress over not being able to fulfil the administrative requirements of the school boards.

Similar to in Shanghai, local Quebec school boards receive funding according to the number of legally-resident children enrolled in their schools. Unable to provide the necessary documents, undocumented children were not funded by the Ministry of Education. So, unless 
the school boards were able to make them pay tuition, their education was a drain on the already cash-strapped school boards budget. This being said, neither the school boards nor the Ministry of Education wanted to be responsible for the exclusion of undocumented children from school (Meloni et al. 2016).

A compromise was struck in 2013, whereby the Ministry of Education agreed to fund the education of children who had a letter of assessment from a publicly-employed social worker that attested to the need of the child to attend school for their health development. This "back door" to the education system is far from perfect - nor is it secure, especially as the provincial government is in a campaign of austerity - but it is functioning.

There remain important problems. First, the current system to provide free access to education is difficult and stressful for undocumented families. Second, schools remain a place where, again, through unofficial channels, undocumented children and their families are sometimes denounced to immigration authorities and apprehended. Because of this, substandard private schools become an alternative for many families. Finally, any access to education is closed to undocumented youth at the post-secondary level once they turn 18. For adults, only community-based, informal education programs are open to them.

\section{Access to education for migrant children in Shanghai}

In Chinese society, education is widely viewed as an effective means to achieve upward social mobility, and many migrants bring their children to cities for better education and life opportunities. However, due to lack of an urban hukou, many rural-to-urban migrant children were previously denied entry to the urban public education system. This is because education is a social entitlement attached to local hukou registration, local governments are allocating 
resources based on the number of children registered within their jurisdiction. When children moved from rural to urban jurisdictions, it was difficult for rural governments to transfer resources to the urban jurisdiction, leaving host cities without any educational dollars for these children.

The central government began addressing this problem of lack of education for children in 1996, stipulating that migrant children should be given access to urban compulsory education, and urged municipalities to accept migrant children age between 6 and 14 in staterun or privately-run migrant children's schools under the status of temporary students (Dong 2010; Wei \& Hou, 2010).

Despite remarkable progress in national education policies, local governments remain almost entirely responsible for funding schools with little support from central government. Some municipalities remain resistant to giving migrant children full and equal access to education (Dong, 2010; Kwong, 2011). Shanghai, however, has been very responsive to central government's policies to meet education needs of children of migrant workers. Public schools were encouraged to accept migrant children, and more state-subsidized schools were set up to accommodate migrant children for their compulsory education.

These measures have attracted more migrants coming to Shanghai with children, which poses more pressure on government to meet their educational needs. There have been setbacks, however, with Shanghai attempting to limit the arrival of new migrants and strengthen their management of this population. Since 2014, migrant families have been required to submit proof of their residence in Shanghai for the last two years and of their contributions to local social insurance programs for six continuous months in order for their children to qualify to 
attend public schools (Shanghai Education News, 2013). This effective eliminated access to public education for many migrant children whose parents were self-employed or worked in informal service sectors where did not want to contribute for their employees.

Moreover, secondary and post-secondary education in cities is still problematic for migrant children. All university candidates, for example, must take university entrance exams in their place of hukou registration. Because school districts have different syllabi that are reflected in the university entrance exams, migrant children must also leave their parents to complete their high school in their community of hukou registration if they hope to be competitive in the exams.

\section{Access to housing}

\section{Access to housing for migrants in Quebec}

Access to housing in Quebec takes three forms: home ownership, commercial rental housing and, to a much lesser degree, subsidized social housing. Undocumented migrants, and most precarious migrants in general, are totally excluded from any form of public subsidy for housing but have full access to the private housing - according to their financial capacity (Rose and Charette 2014). Undocumented migrants in Canada are typically surviving at a subsistence economic level and find themselves relegated to a secondary housing market of poor-quality rental housing, often overcrowded (Ives et al. 2014). If they run into conflict with their landlord (ex. refusal to do repairs, abusive rent hikes), undocumented migrants would have full access to the provincial Rental Board, which mediates such conflicts. However, unscrupulous landlords having been known to take advantage of undocumented migrants, threatening to 
report them to immigration authorities if they complain or resist poor treatment (Walsh et al. 2015).

\section{Access to housing for migrants in Shanghai}

Urban residents are able to obtain accommodation through one of three methods: buying property outright; paying higher rent for publicly-assigned apartments; or acquiring commercial rental housing through market mechanisms and participating in Affordable Homeownership Projects. A limited number of low-income urban families have the further option of obtaining subsidized low-rent public housing. Other than market-driven commercial housing, therefore, access to housing in the city is state-subsidized and based on hukou status; most rural-to-urban migrants are therefore excluded from access (Wu, 2002). Given the very high price of commercial housing and the limited financial capability of rural-to-urban migrants, the most common housing choice for migrant workers in Shanghai is cheap, poorquality rental housing, followed by dormitories provided by their employers. Many of them can only find affordable housing in impoverished urban areas or city outskirts, especially during their initial settlement. These residential areas for migrant workers are known as "urban villages", often characterized by high residential mobility and density, informal and substandard housing units, limited infrastructure, poor safety and hygiene, and social disorder. While there are no official statistics, there were an estimated 104 urban villages in Shanghai (Sun, 2013). 


\section{Discussion and conclusion: the production of social exclusion and its influence on individual and social outcomes}

In this article, we have discussed the ways in which central and local policy frameworks have intersected to create the social exclusion of undocumented migrants in Quebec, Canada and Shanghai, China, thwarting people's true capabilities (Sen, 2000), denying them access to important resources and restricting them to a situation of uncertainty and precarity (Meloni et al. 2014, Goldring, Berinstein, and Bernhard 2009, Chan 2010, Wu 2010). While the two contexts differ in many ways, particularly in terms of scale and international versus internal migration, they share a rapid growth in an undocumented population of migrant workers that has led policymakers to struggle to catch up to the new reality, even acknowledging to some degree the inevitability of this migration in the face of both push and pull factors. In both cases, the initial state reaction was punitive and exclusionary, but over time there have been certain openings to trying to address the human and social rights of these migrants, uneven between the two contexts. In this discussion, we reflect on the dangers of maintaining a policy of social exclusion from both an individual and a social perspective. We then conclude with a consideration of the degree to which a temporary residency permits address the problems of social exclusion.

\section{What's the impact on migrants themselves?}

In our respective studies, it emerged that the social exclusion created by these policy frameworks had impacts far beyond simple exclusion from social benefits. In Montreal, the focus was on civil society organizations advocating for the rights of undocumented migrants 
(Hanley et al. 2006, Hanley et al. 2012), while in Shanghai, data collection included rural-tourban migrant children, their families and social workers engaged in a case study urban village (Wen and Hanley 2015b, a). In both contexts, however, what emerged for undocumented migrants was a life of great stress related to their uncertain status in their new home.

Undocumented migrants in both Quebec and Shanghai experience a sense of social exclusion in their daily lives and a feeling that it is impossible to make real plans for the future. In navigating the city, they fear being asked to justify their presence (potentially leading to deportation in the Canadian case) and feel less entitled to enjoy the benefits of city life. This is particularly true in Shanghai's case, where migrant workers have made major economic contribution in the city's process of becoming one of the richest international metropolitans. However, after being exploited for their labour value, aging migrant workers find themselves unable to stay in the city with a decent life, let alone ensure a promising future for their children. Their exclusion from affordable health care, public education and affordable, decent housing creates frustration and shame. Workers fear unemployment or lasting injury from their jobs; unless they work, their life in the city would become destitute. The stress can strain family relations and lead to mental health challenges. Undocumented migrants feel like second-class citizens.

This being said, for many undocumented migrants in both contexts, the alternative of returning to their communities of origin seems worse. In their home communities, they perceive lesser employment, health and educational opportunities. Although their lives are difficult in their new homes, they consider themselves to be drawing immediate, if meagre, financial benefit for their families and they expect their children to have access to much greater 
opportunities in the future.

\section{What's the social impact of the exclusion of undocumented migrants?}

In both Canada and China, there is a dual process of: on the one hand, a growing acceptance of the counter-productivity of the exclusion of undocumented migrants from social services, especially for children; and, on the other, a fear of this unknown and uncontrolled population. So while there are signs of openness in both contexts (back door to free public education in Quebec, possibility of changing hukou registration in China), there are also signs of crackdowns (increased immigration enforcement in Canada, increased school restrictions in Shanghai).

Nevertheless, there are definite negative consequences of two-tiered employment, health, education and housing systems. In all cases, the presence of a subpopulation unable to protect or promote their rights creates downward pressure for the whole system. It is difficult to pursue decent wages, for example, when there is a group of workers forced to accept lesser conditions. Public health is difficult to protect when there is a sub-population that avoids contact with health services. A less educated population is a drain on the overall economy, especially considering that many of the children excluded will eventually manage to regularize their status as adults. And the growth of informal and substandard housing arrangements poses problems for urban planning and public safety.

In this light, it would seem that both Canada and Shanghai are grappling with inevitability of irregular migration. Canada depends on migration for its economic and social wellbeing and, given the complexity of the current immigration system, it is inevitable that people will fall 
through the cracks and become undocumented. While it seems possible for Canada to erect greater obstacles to entry to the country for those without legal permission, there is little to be done once people do enter legally. Once inside the country, irregular migrants are nearly impossible to distinguish from the immigrants in the general population, making effective enforcement extremely politically problematic. In Shanghai, the number of irregular migrants is overwhelming. The local economy has come to rely on their presence as both workers and consumers. And, without the presence of internal border controls, a highly unpalatable option, it is virtually impossible to block their movement.

It would seem, therefore, that, in both cases, the state is more likely to find success in managing this population through regularization than exclusion.

\section{Are temporary permits the answer?}

Both China and Canada have, at this point, extensive experience with temporary work/resident permits for migrants. Such permits can offer both management of the population and facilitate access to social welfare system, including the allocation of necessary resources to the local authorities providing social services. Temporary work/resident permits offer migrants a legal status and some degree of security. They also offer a possibility of linking migration to true labour market needs.

But experience in Canada and China shows several limitations to addressing the problems raised in this article. Such permits rarely give full access to the social welfare system for workers and their family members are rarely included in such schemes, leading to problematic family separation or certain families accompanying the worker as undocumented migrants. The temporary, dependent nature of the permits are a barrier to full realization of social rights, 
particularly when the objective of the family is to settle permanently and invest in their futures. And, finally, the rights attached to such temporary permits are easily rescinded, as we have seen in recent years in both Canada (the 4-and-4 rule) and in China (Shanghai's education restrictions).

It seems that, in China, there is some recognition of the problems with temporary permits. As of January $1^{\text {st }}, 2016$, the entire country is moving instead towards the allocation of (permanent) resident permits for internal migrants, a status in parallel with Canada's permanent resident status for international migrants. While the extension of China's resident permits does offer increased security for internal migrants, it is still a step away from allowing rural-to-urban migrants the possibility of changing their hukou registration to the local urban hukou (the equivalent of urban citizenship). Moreover, it is a fairly new policy, and its effectiveness in improving the life and situation for migrant workers still needs time to verify.

In Canada, however, the federal government under the Conservative party was going in the opposite direction, making it harder than ever for migrants to become permanent residents, as evidenced in the recent reforms to immigration policy, particularly changes to the Live-In Caregiver Program and restrictions on family reunification. We will see if there are significant changes under the newly elected (October 2015) Liberal Party; their electoral platform does offer some hope for improvement.

The need remains to recognize the human, social and economic imperative of offering stable and secure status for lower-tier economic migrants. The continued denial of these rights - their social exclusion - is a reflection of states' denial of the reality of both the economic demands within their own economies and the push factors in the communities that migrants 
feel forced to leave in search of better lives.

\section{Acknowledgements}

The authors would like to recognize the helpful contributions of the participants of the Social Policy and Social Protection in Asia 2015 Workshop conference in Hong Kong, July 2015, as well as those of Drs. Meihua Zhu and Wendy Thomson who were members of the advisory committee for the Shanghai case study. 


\section{References}

Arbel, Efrat, and Alletta Brenner. 2014. "Bordering on failure: Canada-US border policy and the politics of refugee exclusion." Harvard Immigration and Refugee Law Clinical Program, Harvard Law School (Cambridge, MA: 2013).

Bond, Jennifer, and David Wiseman. 2014. "Shortchanging Justice: The Arbitrary Relationship between Refugee System Reform and Federal Legal Aid Funding." Shortchanging Justice: The Arbitrary Relationship between Refugee System Reform and Federal Legal Aid Funding”(2014) 91 (3).

Campbell, Ruth M, Klei, AG, Hodges, Brian D, Fisman, David, \& Kitto, Simon. (2014). A comparison of health access between permanent residents, undocumented immigrants and refugee claimants in Toronto, Canada. Journal of Immigrant and Minority Health, 16(1), 165-176.

Chan, Kam Wing. 2010. The household registration system and migrant labor in China: notes on a debate. Population and development review, 36(2), 357-364.

Chan, K, W. \& Zhang, L. (1999). The hukou system and rural-urban migration in China: Processes and changes. The China Quarterly, 160: 818-855.

Cheng, Z. M., Russell, S., \& Fei, G. (2015). The impact of China's new Labour Contract Law on socioeconomic outcomes for migrants and urban workers. Human Relations, 68(3): 329-352.

Citizenship and Immigration Canada (CIC). (2015). Canada - Permanent residents by gender and category, 1989 to 2014. Facts and figures 2014 - Immigration overview: Permanent residents. Ottawa: CIC.

Citizenship and Immigration Canada (CIC). (2014). Work permit holders for work purposes with valid permit(s) in calendar year. Facts and figures 2013 - Immigration overview: Temporary residents. Ottawa: CIC.

Crépeau, François, and Delphine Nakache. 2006. "Controlling Irregular Migration in CanadaReconciling Security Concerns with Human Rights Protection." IRPP Choices 12 (1).

Deshingkar, Priya and Grimm, Sven. 2005. Internal Migration and Development: A Global Perspective. Geneva: IOM.

Dong, J. (2010). Neo-liberalism and evolvement of China's education policies on migrant children's schooling. Journal of Critical Education Policy Studies, 8(1): 137-160. 
Duan, C. R., \& Yang, K. (2009). Status quo of migrant population in China---An analysis based on 2005 National 1\% population sample survey. Population \& Society, 25: 5-9.

Ellis, B. D. (2015). The production of irregular migration in Canada. Canadian Ethnic Studies, 47(2), 93-112.

Faraday, Fay. 2012. Made in Canada: How the Law Constructs Migrant Workers' Insecurity: Metcalf Foundation.

Faraday, Fay. 2014. "Profiting from the Precarious: How recruitment practices exploit migrant workers." Toronto: Mecalf Foundation. Accessed April 10:2014.

Foster, Jason. 2012. "Making temporary permanent: the silent transformation of the temporary foreign worker program." Just Labour 19.

Fudge, Judy, and Fiona MacPhail. 2009. "The temporary foreign worker program in Canada: Low-skilled workers as an extreme form of flexible labour." Comparative labor law and policy journal 31:101-139.

Goldring, ., Berinstein, C. \& Bernhard, J.K. 2009. "Institutionalizing precarious migratory status in Canada." Citizenship studies 13 (3):239-265.

Goldring, Luin, \& Landolt, Patricia. 2013. Producing and negotiating non-citizenship: Precarious legal status in Canada: University of Toronto Press.

Hanley, J. (2007). La gauche militante dans les luttes pour les droits des sans-papiers: incontournable et contestée au Québec. In J. Gotovitch, A. Morelli, and S. Jaumain (eds.), Contester dans un pays prospère. Brussels: PIE-Peter Lang.

Hanley, Jill, Sylvie Gravel, Katherine Lippel, and Jah-Hon Koo. 2014. "Pathways to Healthcare for Migrant Workers: How Can Health Entitlement Influence Occupational Health Trajectories?" Perspectives interdisciplinaires sur le travail et la santé (162).

Hanley, J., Oxman-Martinez, J., Lacroix, M., \& Gal, S. 2006. "The" Deserving" Undocumented?: Government and Community Response to Human Trafficking as a Labour Phenomenon." Labour, Capital and Society/Travail, capital et société:78-103.

Hanley, J, Shragge, E. Rivard, A, Koo, J. 2012. "Good enough to work? Good enough to stay!" Organising among temporary Foreign Workers, dans Patti Tamara Lenard and Christine Straehle (ed.), Legislated Inequality. Temporary Labour Migration in Canada, Montreal \& Kingston, McGill-Queen'University Press 407:245-271.

Hick, Rod. 2012. The capability approach: insights for a new poverty focus. Journal of Social 
Policy, 41(02), 291-308.

International Labour Organisation. 2015. ILO Global estimates on migrant workers: Results and methodology. Geneva: ILO.

Ives, Nicole, Jill Hanley, Christine A Walsh, and David Este. 2014. "Transnational elements of newcomer women's housing insecurity: remittances and social networks." Transnational Social Review 4 (2-3):152-167.

Jackson, Samantha, and Harald Bauder. 2014. "Neither temporary, nor permanent: The precarious employment experiences of refugee claimants in Canada." Journal of Refugee Studies 27 (3):360-381.

Kwong, J. (2011). Education and identity: The marginalization of migrant youths in Beijing. Journal of Youth Studies, 14(8): 871-883.

Lee, L. (2012). Decomposing wage differentials between migrant workers and urban workers in urban China's labour markets. China Economic Review, 23: 461-470

Li, B. (2007). Why do migrant workers not participate in urban social security schemes? The case of the construction and service sectors in Tianjin. In I. Nielsen \& R. Smyth (Eds.), Migration and Social Protection in China (pp. 92-117). Singapore: World Scientific Publishing Co. Pte. Ltd.

Liu, W. J. (2001). The reform in hukou system should not be delayed. Reading, 12: 99-103.

Liu, M. (2007). A study on the problems of social security for rural-to-urban migrant workers. Journal of the Party School of the Central Committee of the C.T.C., 11(1): 78-83.

Magalhaes, L., Carrasco, D. \& Gastaldo, D. 2010. "Undocumented migrants in Canada: a scope literature review on health, access to services, and working conditions." Journal of Immigrant and Minority Health 12 (1):132-151.

Meloni, Francesca. 2013. "Living with Uncertainty: An Ethnographic Study on the Agency and Belonging of Undocumented Youth in Canada." McGill University.

Meloni, Francesca, Cécile Rousseau, Catherine Montgomery, and Toby Measham. 2014. "Children of exception: Redefining categories of illegality and citizenship in Canada." Children \& Society 28 (4):305-315.

Meloni, Francesca, Cecile Rousseau, Alexandra Ricard-Guay, and Jill Hanley. 2016, forthcoming. "Making Visible the Invisible: Experiences of an Action Research Project on Access to Education for Undocumented Children in Canada." International Journal of Migration, Health \& Social Care. 
National Bureau of Statistics. (2000). China Statistical Yearbook 2000.

National Bureau of Statistics. (2011). China Statistical Yearbook 2011.

National People's Congress. (2007). New Labour Contract Law. Retrieved from http://www.gov.cn/flfg/2007-06/29/content_669394.htm at September 18, 2015.

Oxman-Martinez, Jacqueline, Jill Hanley, Lucyna Lach, Nazilla Khanlou, Swarna Weerasinghe, and Vijay Agnew. 2005. "Intersection of Canadian policy parameters affecting women with precarious immigration status: A baseline for understanding barriers to health." Journal of Immigrant and Minority Health 7 (4):247-258.

Preibisch, Kerry, \& Otero, Gerardo. 2014. Does citizenship status matter in Canadian agriculture? Workplace health and safety for migrant and immigrant laborers. Rural sociology, 79(2), 174-199.

Protecteur du citoyen. 2014. Accès à l'éducation publique pour les enfants en situation d'immigration précaire. Québec: Assemblée nationale du Québec.

Rose, Damaris, and Alexandra Charette. 2014. "Housing Experiences of Users of Settlement Services for Newcomers in Montreal: Does Immigration Status Matter?" Immigrant Integration: Research Implications for Future Policy, Conference Proceedings, Canadian Scholars' Press Inc.

Rousseau, Cécile, Audrey Laurin-Lamothe, Joanna Anneke Rummens, Francesca Meloni, Nicolas Steinmetz, and Fernando Alvarez. 2013. "Uninsured immigrant and refugee children presenting to Canadian paediatric emergency departments: Disparities in help-seeking and service delivery." Paediatrics \& child health 18 (9):465.

Rousseau, Cecile, Alexandra Ricard-Guay, Audrey Laurin-Lamothe, Anita J Gagnon, and Hélène Rousseau. 2014. "Perinatal health care for undocumented women in Montreal: When sub-standard care is almost the rule." Journal of Nursing Education and Practice 4 (3):p217.

Rousseau, Cécile, Sonia Ter Kuile, Marie Muňoz, Lucie Nadeau, Marie-Jo Ouimet, Laurence Kirmayer, and François Crépeau. 2008. "Health care access for refugees and immigrants with precarious status: public health and human right challenges." Canadian Journal of Public Health 99 (4):290-292.

Sassen, Saskia. 2002. "Towards post-national and denationalized citizenship." Handbook of citizenship studies:277-292.

Sen, Amartya. (2000). Social exclusion: Concept, application, and scrutiny. Social 
Development Papers, No.1. Manila, Philippines: Office of Environment and Social Development, Asian Development Bank.

Shanghai Education News. (2013). New trends in educational policies for migrant children in Shanghai. Retrieved from http://www.shedunews.com/zixun/shanghai/zonghe/2013/12/24/599228.html at September 17, 2015.

Sikka, Anette, Katherine Lippel, and Jill Hanley. 2011. "Access to Health Care and Workers' Compensation for Precarious Migrants in Quebec, Ontario and New Brunswick." McGill JL \& Health 5:203.

State Council. (2003). Circular of the Opinion on the Improvement of the Services and Management of Migrant Workers. Retrieved from http://202.123.110.5/zwgk/2005$\underline{08 / 12 / \text { content 21839.htm }}$ at September 18, 2015.

State Council. (2006). Opinions on Resolving the Problems Faced by Migrant Workers. Retrieved from http://www.gov.cn/jrzg/2006-03/27/content_237644.htm at September 18, 2015.

Statistics Canada (StatsCan). (2012). The Canadian Population in 2011: Population Counts and Growth. Population and dwelling counts, 2011 Census. Ottawa: Ministry of Industry.

Statistics Canada (StatsCan). (2013). Immigration and Ethnocultural Diversity in Canada, 2011 Census. Ottawa: Ministry of Industry.

Statistics Canada (StatsCan). (2015). Population of Census Metropolitan Areas, Projected from 2011 Census. Ottawa: Ministry of Industry. Available at: http://www.statcan.gc.ca/tablestableaux/sum-som/101/cst01/demo05a-eng.htm

Tilson, D. 2009. Temporary Foreign Workers and Nonstatus Workers. Report of the Standing Committee on Citizenship and Immigration. 40th Parliament, 2nd Session. Ottawa: Library of Parliament.

Vanthuyne, Karine, Francesca Meloni, Monica Ruiz-Casares, Cécile Rousseau, and Alexandra Ricard-Guay. 2013. "Health workers' perceptions of access to care for children and pregnant women with precarious immigration status: Health as a right or a privilege?" Social Science \& Medicine 93:78-85.

Varsanyi, Monica W. 2006. "Interrogating “urban citizenship" vis-à-vis undocumented migration." Citizenship studies 10 (2):229-249.

Walsh, Christine A, Jill Hanley, Nicole Ives, and Shawn Renee Hordyk. 2015. "Exploring the Experiences of Newcomer Women with Insecure Housing in Montréal Canada." 
Journal of International Migration and Integration:1-18.

Wang, C. G. (2006). Issues concerning citizenship treatment and social justice for rural-tourban migrants. Journal of Zhengzhou University (Social science Edition). 37(1): 77-80.

Wang, H. N., Guo, F., \& Cheng, Z. M., (2014). A distributional analysis of wage discrimination against migrant workers in China's urban labour market. Urban Studies, DOI: $10.1177 / 0042098014547367$.

Wang, Yixuan, and Li Zong. 2014. "Temporary Natives, Perpetual Foreigners: The Secondary Status of Temporary Foreign Workers in Canada and Structural Barriers to Their Inclusion." Immigrant Integration: Research Implications for Future Policy:1.

Wei, J. \& Hou, J. (2010). The household registration system, education system, and inequalities in education for migrant children. Chinese Education \& Society, 43(5): 7789.

Wen, Ya, and Jill Hanley. 2015a. "Enhancing Social Support for Migrant Families: A Case Study of Community Services in a Shanghai Urban Village and Implications for Intervention." Asian Social Work and Policy Review.

Wen, Ya, and Jill Hanley. 2015b. "Rural-to-Urban Migration, Family Resilience, and Policy Framework for Social Support in China." Asian Social Work and Policy Review 9 (1):18-28.

Wu, Jieh-min. 2010. Rural migrant workers and China's differential citizenship: A comparative institutional analysis. One country, two societies: Rural-urban inequality in contemporary China, 55-81.

Wu, W. P. (2002). Migrant housing in urban China: Choices and constrains. Urban Affairs Review, 9:90-119.

Xinhua news. (2013). Shanghai implementing score management for migrant workers to receive equal public services. Retrieved from http://news.xinhuanet.com/201307/01/c 116358747.htm at Sept. 8, 2015.

Xu, Q. W., Guan, X. P. \& Yao, F. F. (2011). Welfare program participation among rural-tourban migrant workers in China. International Social Welfare. 20: 10-21.

Zhu, Y. (1999). New Paths to Urbanization in China: Seeking More Balanced Patterns, New York: Nova Science Publications, Inc. 